\title{
The Effects of Coexisting Copper, Iron, Cobalt, Nickel, and Zinc Ions on Gold Recovery by Enhanced Cementation via Galvanic Interactions between Zero-Valent Aluminum and Activated Carbon in Ammonium Thiosulfate Systems
}

\author{
Sanghee Jeon ${ }^{1, *}$, Sharrydon Bright ${ }^{2}$, Ilhwan Park ${ }^{1} \mathbb{D}$, Carlito Baltazar Tabelin ${ }^{3} \mathbb{D}$, Mayumi Ito ${ }^{1}$ \\ and Naoki Hiroyoshi ${ }^{1, *}$ \\ 1 Division of Sustainable Resource Engineering, Faculty of Engineering, Hokkaido University, \\ Sapporo 060-8628, Japan; i-park@eng.hokudai.ac.jp (I.P.); itomayu@eng.hokudai.ac.jp (M.I.) \\ 2 Department of Mining, Chemical and Metallurgical Engineering, Faculty of Engineering, \\ University of Zimbabwe, Harare 00263, Zimbabwe; sharrydonbright@frontier.hokudai.ac.jp \\ 3 School of Minerals and Energy Resource Engineering, The University of New South Wales, \\ Sydney, NSW 2052, Australia; c.tabelin@unsw.edu.au \\ * Correspondence: shjun1121@eng.hokudai.ac.jp (S.J.); hiroyoshi@eng.hokudai.ac.jp (N.H.); \\ Tel.: +81-11-706-6918 (S.J.)
}

Citation: Jeon, S.; Bright, S.; Park, I.; Tabelin, C.B.; Ito, M.; Hiroyoshi, N. The Effects of Coexisting Copper, Iron, Cobalt, Nickel, and Zinc Ions on Gold Recovery by Enhanced

Cementation via Galvanic

Interactions between Zero-Valent Aluminum and Activated Carbon in Ammonium Thiosulfate Systems. Metals 2021, 11, 1352. https:// doi.org/10.3390/met11091352

Academic Editor: Felix A. Lopez

Received: 30 July 2021

Accepted: 25 August 2021

Published: 27 August 2021

Publisher's Note: MDPI stays neutra with regard to jurisdictional claims in published maps and institutional affiliations.

Copyright: (c) 2021 by the authors. Licensee MDPI, Basel, Switzerland. This article is an open access article distributed under the terms and conditions of the Creative Commons Attribution (CC BY) license (https:// creativecommons.org/licenses/by/ $4.0 /)$.

\begin{abstract}
The use of galvanic interactions between zero-valent aluminum (ZVAl) and activated carbon $(\mathrm{AC})$ to recover gold $(\mathrm{Au})$ ions is a promising technique to overcome the challenges due to the poor recovery in ammonium thiosulfate systems, but the applicability to practical Au ore processing remains elusive so far. The present study describes (1) the recovery of Au ions from low Au concentrations, which are typical concentrations used in Au ore processing; and (2) an investigation into the effects of various coexisting base metal ions that can be present in pregnant ore-leached solutions. The results showed that high Au recovery (i.e., over 85\%) was obtained even at low Au concentrations under the following conditions: 1:1 of $0.15 \mathrm{~g}$ of $\mathrm{ZVAl}$ and $\mathrm{AC}$ with $10 \mathrm{~mL}$ of ammonium thiosulfate solution containing $5 \mathrm{mg} / \mathrm{L}$ of $\mathrm{Au}$ ions at $25^{\circ} \mathrm{C}$ for $1 \mathrm{~h}$ in an anoxic atmosphere. Selected coexisting metal ions (i.e., copper, iron, cobalt, nickel, and zinc) were studied to establish their effects on Au recovery, and the results showed that the Au recovery was enhanced (about 90\%) when copper ions coexist in the solution with minimal effects from other competing base metal ions.
\end{abstract}

Keywords: ammonium thiosulfate; gold; cementation; galvanic interaction; zero-valent aluminum; activated carbon

\section{Introduction}

Changing international regulations, consumer perceptions, and investor expectations in recent years have pushed for more sustainable and eco-friendly mineral processing and metal extraction technologies [1,2]. In gold (Au) hydrometallurgy, cyanide-based technologies such as carbon-in-pulp (CIP) and carbon-in-leach (CIL) remain widely used in both medium- and large-scale Au mining operations [3]. Unfortunately, cyanide is a very toxic compound that poses serious environmental and health hazards when improperly handled and disposed of, so its use is strictly controlled and prohibited in many countries [1,4].

Among the many alternative methods for Au extraction, copper $(\mathrm{Cu})$-catalyzed ammonium thiosulfate leaching is one of the most promising because it uses lixiviants that are non-toxic and less corrosive (Equation (1)) [4,5].

$$
\mathrm{Au}+5 \mathrm{~S}_{2} \mathrm{O}_{3}{ }^{2-}+\mathrm{Cu}\left(\mathrm{NH}_{3}\right)_{4}{ }^{2+} \rightarrow \mathrm{Au}\left(\mathrm{S}_{2} \mathrm{O}_{3}\right)_{2}{ }^{3-}+4 \mathrm{NH}_{3}+\mathrm{Cu}\left(\mathrm{S}_{2} \mathrm{O}_{3}\right)_{3}{ }^{5-}
$$


Furthermore, this approach is effective for the treatment of secondary resources such as e-wastes that contain various types of materials such as plastics, resins, and ferrous, base, and precious metal alloys. Ha et al. [6], for example, reported that over $98 \%$ of $\mathrm{Au}$ was leached from waste mobile phones. Similarly, Jeon et al. [7] successfully leached 99\% of $\mathrm{Au}$ from the printed circuit boards (PCBs) of waste mobile phones under the following conditions: $1 \mathrm{M}$ of thiosulfate, $1 \mathrm{M}$ of ammonia/ammonium, and $10 \mathrm{mM}$ of $\mathrm{Cu}$ ions for $24 \mathrm{~h}$ at $25{ }^{\circ} \mathrm{C}$. Another potential application of $\mathrm{Cu}$-catalyzed ammonium thiosulfate leaching is in the treatment of carbonaceous-type and pyritic Au ores that are unsuitable for cyanidebased methods with the absence of preg-robbing. As a result, remarkable leaching studies for $\mathrm{Au}$ ores also have been reported as follows: Molleman and Dreisinger [8] extracted about $84 \%$ of $\mathrm{Au}$ from pyritic Au concentrate after $24 \mathrm{~h}$ using this method, while Ficeriova et al. [9] dissolved 99\% of Au within 45 min with complex sulfide concentrates. Despite these promising results, applications of $\mathrm{Cu}$-catalyzed ammonium thiosulfate leaching in industrial-scale plants remain limited to date because an acceptable method for Au ion recovery from pregnant leach liquors/solutions remains elusive [4,7].

Conventional CIP and CIL technologies employ activated carbon (AC) to recover Au ions from pregnant leach solutions, an approach that is simple and highly efficient $[1,10]$. Although activated carbon is very efficient when used with cyanide, it is ineffective when thiosulfate is employed because of the low adsorption affinity of the larger, more negative $\mathrm{Au}$ thiosulfate complex adsorption to the AC [1]. According to Navarro et al. [11], Au recovery by AC adsorption from an ammonium thiosulfate medium was only about $50 \%$ after $8 \mathrm{~h}$. Cementation (reductive precipitation), an electrochemical process whereby $\mathrm{Au}$ ions are reduced to metallic Au by reductants, is also a well-established recovery technique for cyanide-based technologies. Metal reductants or cementation agents such as zerovalent base metals (e.g., copper $(\mathrm{Cu})$, zinc $(\mathrm{Zn})$, aluminum $(\mathrm{Al})$, and iron $(\mathrm{Fe})$ ) are often used. In ammonium thiosulfate, however, cementation of $\mathrm{Au}$ ions is difficult because of various unwanted side reactions [7,12-15]: (1) reduction of $\mathrm{Cu}$ ions employed as a catalyst; (2) dissolution of the cementation agents, which leads to high reagent consumption; and

(3) formation of oxide/sulfide layers on cementation agents that inhibit Au recovery. Furthermore, abundant sulfur and $\mathrm{Cu}$ ions present in the solution restrict the application of solvent extraction and electrowinning for Au ion recovery $[1,15]$.

In our previous study, a novel recovery technique that uses synergistic interactions between zero-valent aluminum (ZVAl) and AC for enhanced Au recovery in the ammonium thiosulfate system was developed [15]. The results showed that ZVAl or AC alone could not recover $\mathrm{Au}$ ions, consistent with the results of many previous studies. When mixed, however, over $99 \%$ of $\mathrm{Au}$ ions could be recovered through the following mechanisms: (i) ZVAl acts as an electron donor while AC as an electron mediator to an Au thiosulfate complex; and (ii) making a galvanic cell, which finally leads to enhanced Au recovery [15]. Although the previous study established a high recovery of $\mathrm{Au}$ ions from ammonium thiosulfate solutions, this was obtained in a model solution, which contains only a high concentration of $\mathrm{Au}$ ions. This means that the applicability of this technique to real Au ore processing and/or e-waste recycling with a low $\mathrm{Au}$ ion concentration and coexisting metal ions remains untested.

The present study aims to assess the applicability of this simple and highly efficient novel recovery technique (ZVAl-AC recovery technique) to real Au ore processing. The objectives of this paper are specifically as follows: (a) to recover Au from the solution with less than $10 \mathrm{mg} / \mathrm{L} \mathrm{Au}$, and (b) to investigate the effects of various coexisting metal ions on Au recovery. The previous study on Au ion recovery by the ZVAl-AC technique obtained high $\mathrm{Au}$ recovery (i.e., 99\%) from the solutions but contained a $100 \mathrm{mg} / \mathrm{L}$ concentration of $\mathrm{Au}$ ions, which is much higher than the typical Au concentration in ores. There are surely mines containing high Au concentrations such as $150 \mathrm{~g} / \mathrm{t}$ in Australia [16], $94 \mathrm{~g} / \mathrm{t}$ in Korea [17], and $60 \mathrm{~g} / \mathrm{t}$ in China [18], but those mines with high Au contents have been actively explored; hence, currently operating/investigating mines mainly deal with refractory or complex ores with relatively low Au concentrations such as $6 \mathrm{~g} / \mathrm{t}$ in Laos [19], 
$6.2 \mathrm{~g} / \mathrm{t}$ in China [20], $6.2 \mathrm{~g} / \mathrm{t}$ in Iran [21], or $11.2 \mathrm{~g} / \mathrm{t}$ in Ghana [22]. Furthermore, Au ore contains minerals such as pyrite, arsenopyrite, chalcopyrite, and/or malachite in which various elements (e.g., $\mathrm{Cu}, \mathrm{Fe}, \mathrm{Co}, \mathrm{Ni}$, and $\mathrm{Zn}$ ) are incorporated [23-28]. Once these elements are dissolved in the solution, they can affect Au recovery by competing and/or co-depositing with Au during the recovery process. Thus, identification of Au recovery mechanisms in solutions with low Au concentrations and coexisting metal ions will be essential in the industrial-scale application of ammonium thiosulfate leaching.

The first objective was achieved by batch-type experiments in ammonium thiosulfate solution containing only $\mathrm{Au}$ ions (i.e., Au-thiosulfate solution) at low concentrations (i.e., 5 and $10 \mathrm{mg} / \mathrm{L}$ ), while for the second objective, different concentrations of coexisting metal ions (i.e., $\mathrm{Cu}, \mathrm{Fe}, \mathrm{Co}, \mathrm{Ni}$, or $\mathrm{Zn}$ ions) were added to the $\mathrm{Au}$-thiosulfate solutions with and without $\mathrm{Cu}$ ions. The residues were also observed using a scanning electron microscope with energy dispersive $\mathrm{X}$-ray spectroscopy. This study provides a bridge for the application of this simple, highly efficient recovery technique, which has remained in model testing for $\mathrm{Au}$ ore processing, and will be helpful for researchers interested in the recovery of Au ions as well as in the behavior of base metal ions in thiosulfate systems.

\section{Materials and Methods}

\subsection{Recovery of Au Ions from Solutions with a Low Au Concentration}

The stock ammonium thiosulfate solution containing Au ions (i.e., Au-thiosulfate solution) was prepared by dissolving 5 or $10 \mathrm{mg} / \mathrm{L}$ of Au powder $(99.999 \%$, Wako Pure Chemical Industries, Ltd., Osaka, Japan) in an ammonium thiosulfate solution containing $1 \mathrm{M}$ of $\mathrm{Na}_{2} \mathrm{~S}_{2} \mathrm{O}_{3}, 0.5 \mathrm{M}$ of $\mathrm{NH}_{3}, 0.25 \mathrm{M}$ of $\left(\mathrm{NH}_{4}\right)_{2} \mathrm{SO}_{4}$, and $10 \mathrm{mM}$ of $\mathrm{CuSO}_{4}(\mathrm{pH}$ between 9.5 and 10) using a $300 \mathrm{~mL}$ Erlenmeyer flask shaken in a thermostat water bath shaker at $25^{\circ} \mathrm{C}$ for $24 \mathrm{~h}$ with constant shaking at $120 \mathrm{~min}^{-1}$. The concentration of Au ions in the stock solution was measured by inductively coupled plasma atomic emission spectroscopy (ICP-AES, ICPE-9820, Shimadzu Corporation, Tokyo, Japan) (margin of error $= \pm 2 \%$ ). Subsequently, $0.15 \mathrm{~g}$ of ZVAl (99.99\%, Wako Pure Chemical Industries, Ltd., Osaka, Japan) and/or $0.15 \mathrm{~g}$ of AC $(99.99 \%$, Wako Pure Chemical Industries, Ltd., Osaka, Japan) was mixed with $10 \mathrm{~mL}$ of Au-thiosulfate solution in $50 \mathrm{~mL}$ Erlenmeyer flasks at $25^{\circ} \mathrm{C}$ (shaking at $120 \mathrm{~min}^{-1}$ ) under nitrogen purging conditions to remove the dissolved oxygen in the solution. After $1 \mathrm{~h}$, the filtrate and residue were separated by filtration using $0.2 \mu \mathrm{m}$ syringe-driven membrane filters (LMS Co., Ltd., Tokyo, Japan). The residues were washed thoroughly with deionized water $\left(18 \mathrm{M} \Omega \cdot \mathrm{cm}\right.$, Mill- $\mathrm{Q}^{\circledR}$ Integral Water Purification System, Merck Millipore, Billerica, MA, USA), dried in a vacuum oven at $40{ }^{\circ} \mathrm{C}$, and analyzed by a scanning electron microscope with energy-dispersive X-ray spectroscopy (SEM-EDX, Superscan SSX-550, Shimadzu Corporation, Tokyo, Japan). Meanwhile, the concentrations of Au ions remaining in the filtrates were analyzed by ICP-AES. For validity, accuracy, and replicability of results, experiments were conducted in triplicates.

\subsection{Recovery of Au Ions from Solutions Containing Coexisting Metal Ions}

In order to investigate the effects of coexisting metal ions on $\mathrm{Au}$ recovery using the ZVAl-AC technique, Au-thiosulfate solutions together with base metal ions $(\mathrm{Cu}, \mathrm{Fe}, \mathrm{Co}, \mathrm{Ni}$, and $\mathrm{Zn}$ ions) of concentration varying from 0 to $50 \mathrm{mM}$ with and without $\mathrm{Cu}$ ions were prepared. The reagents used as sources of competing ions were analytical-grade powders of $\mathrm{CuSO}_{4} \cdot 5 \mathrm{H}_{2} \mathrm{O}, \mathrm{NiSO}_{4} \cdot 6 \mathrm{H}_{2} \mathrm{O}, \mathrm{FeSO}_{4} \cdot 7 \mathrm{H}_{2} \mathrm{O}, \mathrm{ZnSO}_{4} \cdot 7 \mathrm{H}_{2} \mathrm{O}$, and $\mathrm{CoSO}_{4} \cdot 7 \mathrm{H}_{2} \mathrm{O}$ (Wako Pure Chemical Industries Ltd., Osaka, Japan). Subsequently, $10 \mathrm{~mL}$ of Au-thiosulfate solution containing each base metal ion was purged with ultra-pure $\mathrm{N}_{2}$ to remove any dissolved oxygen, and then mixed with $0.15 \mathrm{~g}$ of ZVAl and AC at $25^{\circ} \mathrm{C}$ for $1 \mathrm{~h}$, shaking at $120 \mathrm{~min}^{-1}$. After the predetermined mixing time, the suspension was filtered and the residues were washed thoroughly with deionized water, dried in a vacuum oven at $40^{\circ} \mathrm{C}$, and analyzed by SEM-EDX. Meanwhile, the filtrates were analyzed by ICP-AES. For validity, accuracy, and replicability of results, experiments were conducted in triplicates. 


\section{Results}

\subsection{Recovery of Au Ions from Solutions Containing a Low Au Concentration}

Figure 1 shows the recovery of $\mathrm{Au}$ ions from the ammonium thiosulfate solution containing $\mathrm{Au}$ concentrations of 5, 10, and $100 \mathrm{mg} / \mathrm{L}$ by ZVAl and AC. Au recovery was calculated according to the following equation:

$$
\text { Au recovery }(\%)=\frac{[A u](i)-[A u](\mathrm{f})}{[A u](i)} \times 100 \%
$$

where $[A u](\mathrm{i})$ and $[A u](\mathrm{f})$ are the initial and final Au concentrations, respectively.

(a)

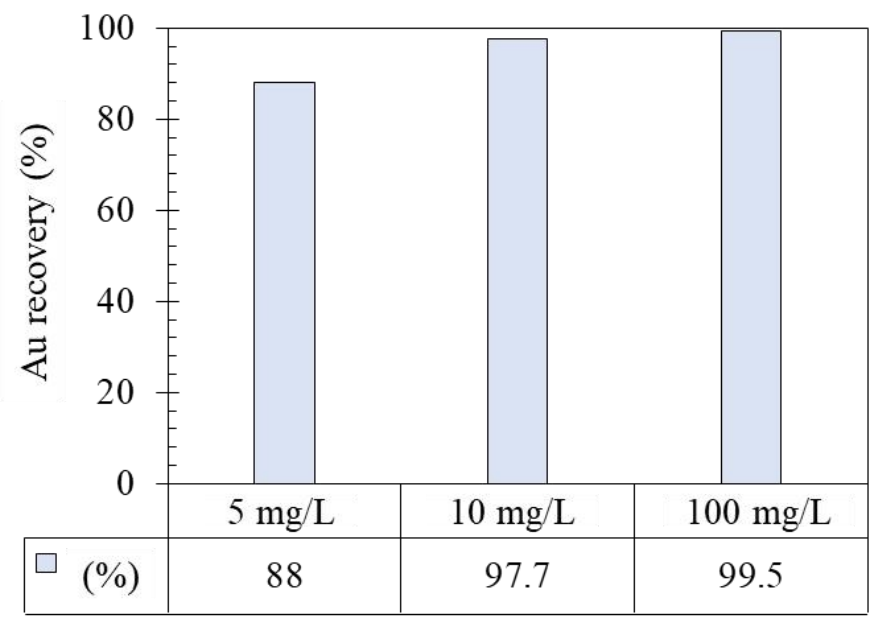

(b)

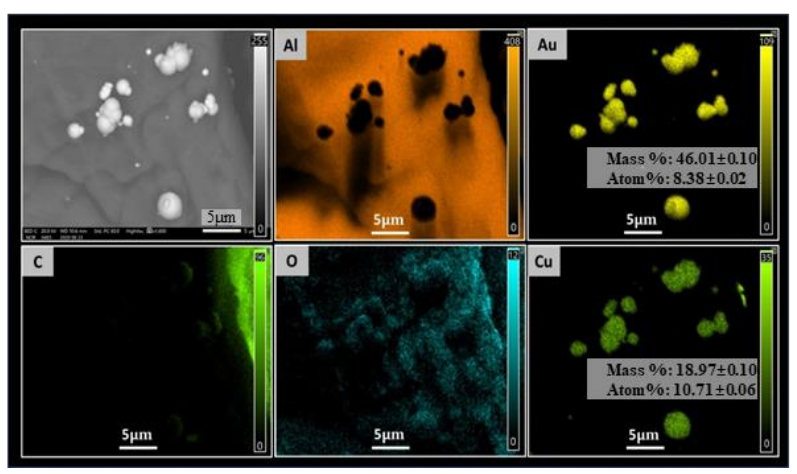

Figure 1. (a) Recovery of Au ions from ammonium thiosulfate solutions with varying initial concentrations from 5 to $100 \mathrm{mg} / \mathrm{L}$, and (b) SEM photomicrographs with corresponding elemental maps of the recovery residue at $10 \mathrm{~mL} / \mathrm{L}$ of $\mathrm{Au}$ initial concentration.

The results showed that over $99 \%$ of $\mathrm{Au}$ was recovered when the initial concentration was $100 \mathrm{mg} / \mathrm{L}$, while about $90 \%$ of Au was recovered when the initial concentration was $5 \mathrm{mg} / \mathrm{L}$. The results indicate that recovery slightly decreases as the initial concentration decreases, similar to the results reported by Wang et al. [29] and Nguyen et al. [30] for the cementation of Au ions, but still showed a high recovery of $90 \%$. Figure $1 \mathrm{~b}$ shows the SEM photomicrographs with corresponding elemental maps of the residue at $10 \mathrm{~mL} / \mathrm{L}$ of $\mathrm{Au}$ initial concentration, and the results showed that $\mathrm{Au}$ and $\mathrm{Cu}$ were detected on the surface of ZVAl.

\subsection{Recovery of $A u$ Ions from Solutions Containing Coexisting Metal Ions}

\subsubsection{Recovery of $\mathrm{Au}$ Ions with Varying $\mathrm{Cu}$ Concentrations in the Solution}

This section focuses on the effects of $\mathrm{Cu}$ ions on Au recovery for the following reasons: 
- $\mathrm{Cu}$ ions are an essential catalyst in ammonium thiosulfate systems, increasing $\mathrm{Au}$ dissolution in ammonium thiosulfate systems 20- to 25-fold (Equation (1)) [1,4];

- $\mathrm{Cu}$ ions could be introduced via the dissolution of $\mathrm{Cu}$ minerals such as chalcopyrite and malachite [23-28] found in Au ores.

Figure 2 presents how $\mathrm{Cu}$ ions affect Au recovery when using ZVAl and AC. The results show that the initial increase in $\mathrm{Cu}$ ion concentration by $10 \mathrm{mM}$ enhanced $\mathrm{Au}$ recovery. This could be attributed to the formation of galvanic cells as a consequence of $\mathrm{Cu}$ cementation. Galvanic interactions enhance electron transfer from ZVAl to the $\mathrm{Au}$ thiosulfate complex, increasing Au recovery [15]. In the second region from 10 to $40 \mathrm{mM}$ $\mathrm{Cu}, \mathrm{Au}$ recovery was high and consistent at about $90 \%$. In this region, all the $\mathrm{Au}$ that can be recovered was already cemented on the $\mathrm{ZVAl}$; hence, increasing $\mathrm{Cu}$ ions did not affect $\mathrm{Au}$ recovery. In the final region above $40 \mathrm{mM} \mathrm{Cu}$, excess $\mathrm{Cu}$ ions began to reduce Au recovery while $\mathrm{Cu}$ precipitation still increased. As shown in Figure 3, the decrease in Au recovery could be attributed to the competition between the reduction of $\mathrm{Cu}$ species (Equations (3) and (4)) and Au species (Equation (5)) [4,7,12].

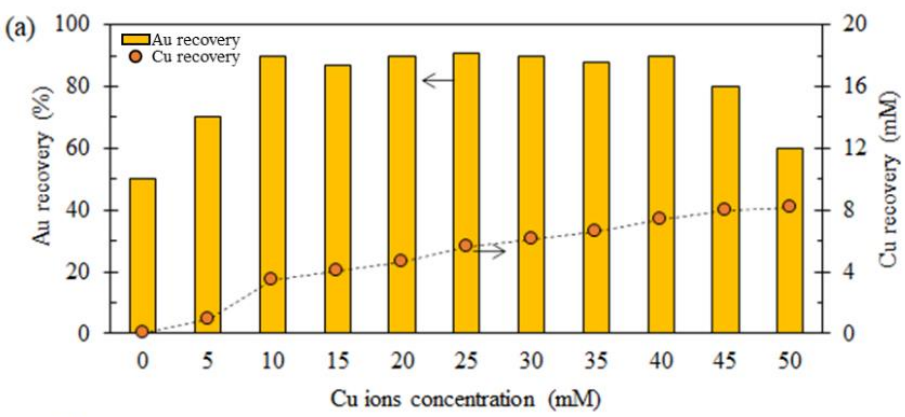

(b)

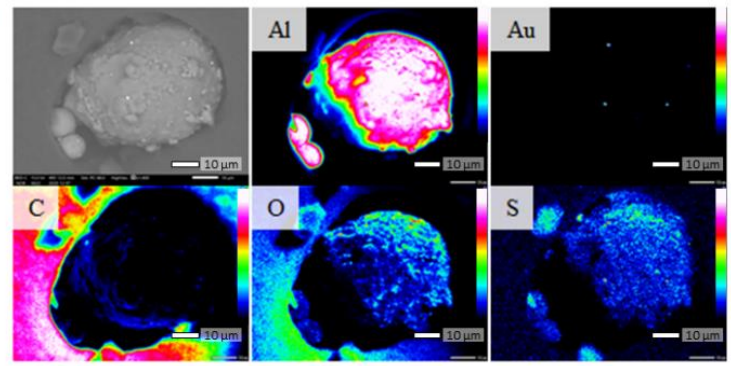

(c)

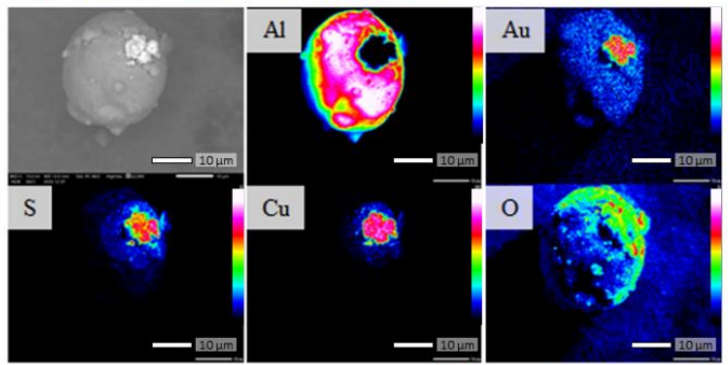

(d)

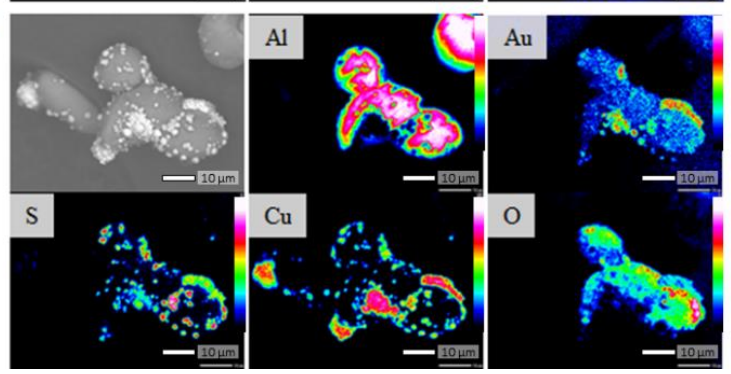

Figure 2. (a) Recovery of gold ions from ammonium thiosulfate solution with varying additions of $\mathrm{Cu}$ ions with concentrations from 0 to $50 \mathrm{mM}$, and SEM photomicrographs with corresponding elemental maps of the residues at (b) $0 \mathrm{mM}$, (c) $10 \mathrm{mM}$, and (d) $50 \mathrm{mM}$ of $\mathrm{Cu}$ ion additions. 


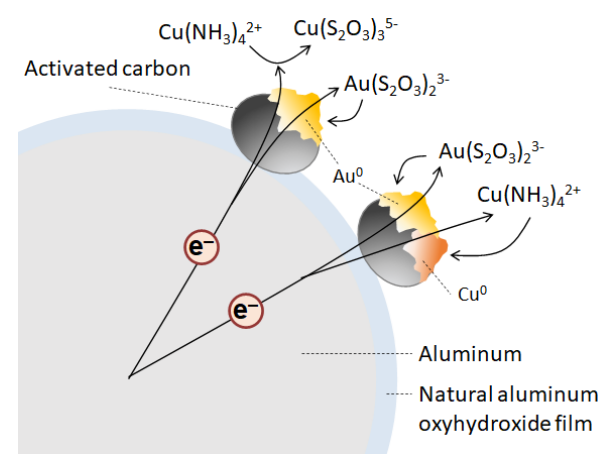

Figure 3. Schematic diagram of the competitive electron transfer from ZVAl to the Cu complex and the Au-thiosulfate complex.

SEM-EDX results showed that in the absence of $\mathrm{Cu}$ ions (residue at $0 \mathrm{mM} \mathrm{Cu}$ ), $\mathrm{Au}$ was recovered as small point-like depositions on the surface of ZVAl (Figure 2b), while the area of $\mathrm{Au}$ deposition increased when $\mathrm{Cu}$ concentration increased by 10 and $50 \mathrm{mM}$ (Figure 2b,c), and showed that deposited Au occurs together with deposited $\mathrm{Cu}$.

$$
\begin{gathered}
\mathrm{Cu}\left(\mathrm{NH}_{3}\right)_{4}{ }^{2+}+3 \mathrm{~S}_{2} \mathrm{O}_{3}{ }^{2-}+\mathrm{e}^{-} \rightarrow \mathrm{Cu}\left(\mathrm{S}_{2} \mathrm{O}_{3}\right)_{3}{ }^{5-}+4 \mathrm{NH}_{3} \\
\mathrm{Cu}\left(\mathrm{NH}_{3}\right)_{4}{ }^{2+}+2 \mathrm{e}^{-} \rightarrow \mathrm{Cu}+4 \mathrm{NH}_{3} \\
\mathrm{Au}\left(\mathrm{S}_{2} \mathrm{O}_{3}\right)_{2}{ }^{3-}+\mathrm{e}^{-} \rightarrow \mathrm{Au}^{0}+2 \mathrm{~S}_{2} \mathrm{O}_{3}{ }^{2-}
\end{gathered}
$$

3.2.2. Recovery of $\mathrm{Au}$ Ions with Varying $\mathrm{Fe}, \mathrm{Co}, \mathrm{Ni}$, and $\mathrm{Zn}$ Concentrations in the Solution

In this part of the study, various metal ions including $\mathrm{Fe}, \mathrm{Co}, \mathrm{Ni}$, and $\mathrm{Zn}$ ions that could coexist in pregnant Au ore solutions were selected and their effects on Au recovery were elucidated.

The effects of Fe ions on Au recovery are shown in Figure 4. Figure 4a,b shows the recovery of Au ions with varying addition concentrations of Fe ions in the absence and presence of $\mathrm{Cu}$ ions in the solution, respectively. In both cases, the results showed that the effects of Fe ions on Au recovery were negligible. This could be explained by the very low solubility of Fe ions under basic conditions [31]; hence, Fe precipitates are readily formed in the solution, which neither favors nor hinders Au recovery. The precipitate in the solution was analyzed by SEM-EDX and showed that Fe precipitates were formed in the solution as shown in Figure 4c. When $10 \mathrm{mM}$ of $\mathrm{Cu}$ ions were added to the solution, Au recovery was enhanced and consistently showed about $85-90 \%$ Au recovery (Figure $4 \mathrm{~b}$ ), which indicates that $\mathrm{Au}$ can be successfully recovered regardless of the presence of Fe ions.

Figure $5 \mathrm{a}, \mathrm{b}$ shows the results of Au recovery with varying Co ion additions without and with $\mathrm{Cu}$ ions, respectively. In the absence of $\mathrm{Cu}$ ions (Figure 5a), Au recovery increased to $60 \%$ with the addition of $1 \mathrm{mM}$ of Co ions, then decreased as the addition of Co ions increased due to the competitive reduction of $\mathrm{Co}$ ions and $\mathrm{Au}$ ions. In the presence of $\mathrm{Cu}$ ions in the solution, however, Au recovery was about $90 \%$, indicating that the negative effects of $\mathrm{Co}$ ions on $\mathrm{Au}$ recovery were hindered in the presence of $\mathrm{Cu}$ ions and high $\mathrm{Au}$ recovery could be obtained (Figure $5 \mathrm{~b}$ ). Figure $5 \mathrm{c}$ presents the residue analysis by SEM-EDX. The results show that $\mathrm{Co}, \mathrm{Au}$, and $\mathrm{Cu}$ were recovered on the surface of $\mathrm{ZVAl}$ and deposition areas of Au were very close to that of $\mathrm{Cu}$.

Figure $6 \mathrm{a}, \mathrm{b}$ shows the effects of $\mathrm{Ni}$ ions on Au recovery with varying concentrations without and with $\mathrm{Cu}$ ions, respectively. The results showed that in the absence of $\mathrm{Cu}$ ions, Au recovery increased to $83 \%$ with the addition of $10 \mathrm{mM}$ of $\mathrm{Ni}$ ions, then recovery decreased as the addition of $\mathrm{Ni}$ ions increased by the competitive reduction. In the presence of $\mathrm{Cu}$ ions, however, Au recovery was constantly high at all ranges of $\mathrm{Ni}$ ion additions [32]. Figure $6 c$ presents the SEM-EDX analysis of the residue, showing that $\mathrm{Ni}, \mathrm{Cu}$, and $\mathrm{Au}$ were co-cemented on ZVAl particles. 
(a)

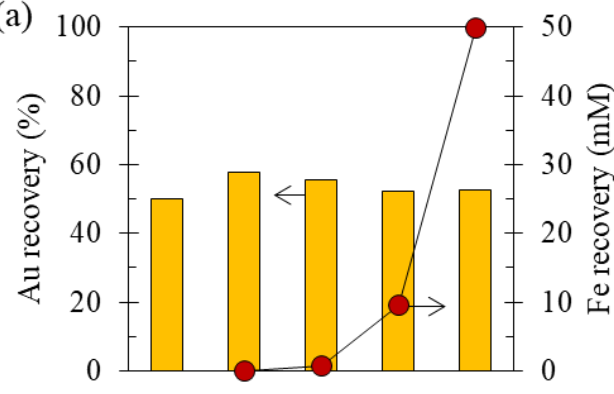

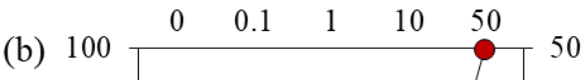

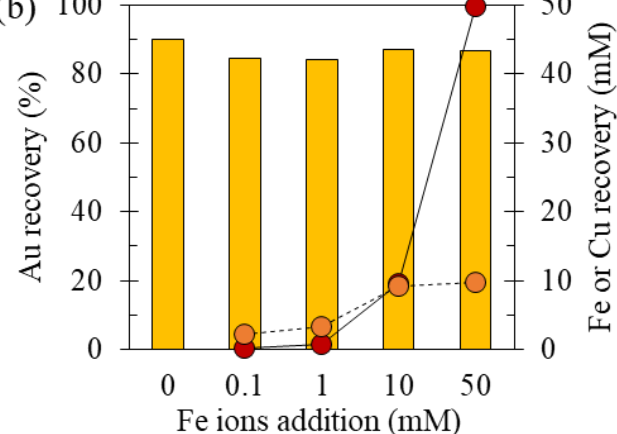

(c)
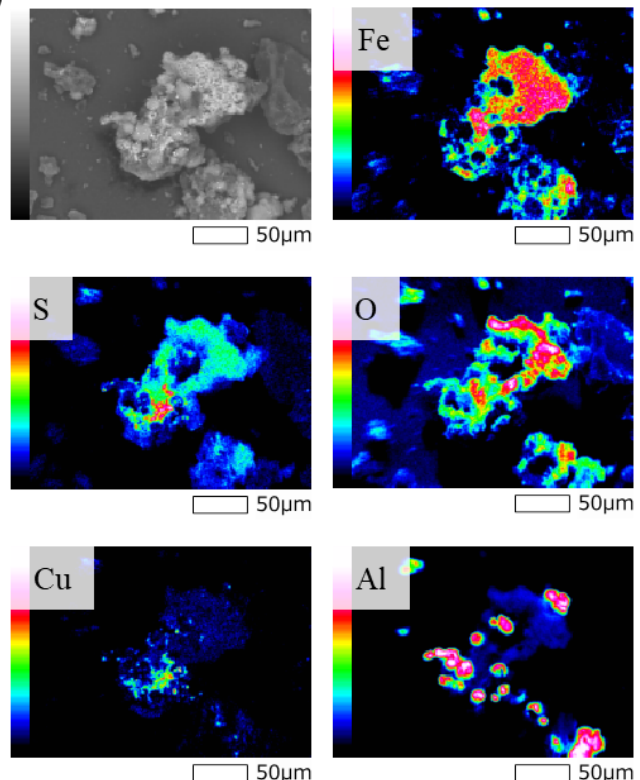

$\square$ Au recovery $\bullet \mathrm{Fe} O \mathrm{Cu}$

Figure 4. Recovery of gold ions from an ammonium thiosulfate solution with varying addition of Fe ion concentrations from 0 to $50 \mathrm{mM}$ (a) without and (b) with $10 \mathrm{mM}$ of $\mathrm{Cu}$ ions in the solution, and (c) SEM photomicrographs with corresponding elemental maps of the precipitates in the solution.

(a)

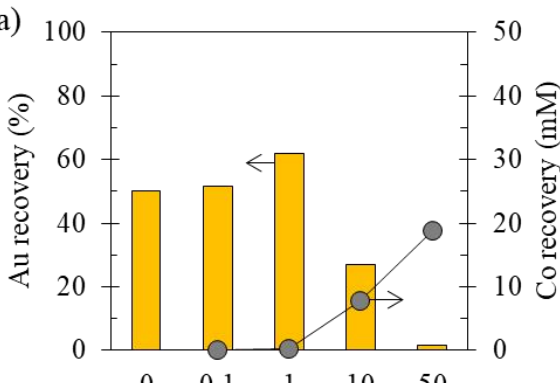

(b)

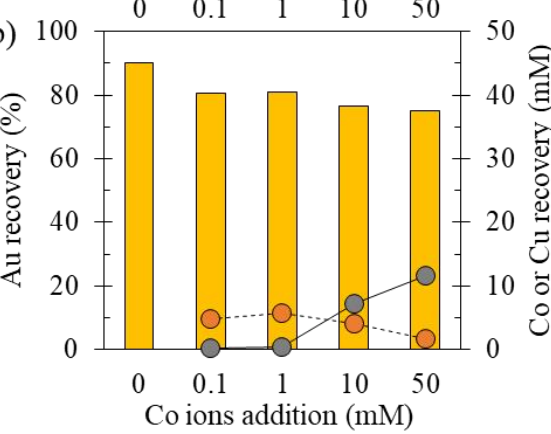

(c)
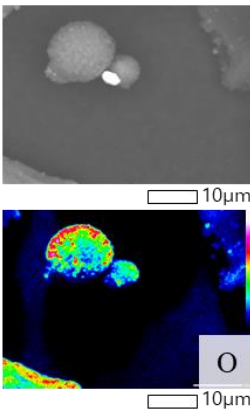

$\mathrm{O}$
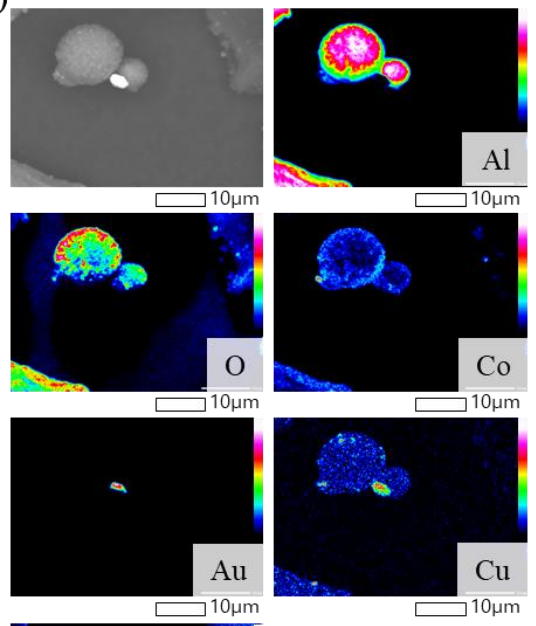

$\mathrm{Cu}$

$\square$ Au recovery $\bigcirc \mathrm{Co} \bigcirc \mathrm{Cu}$

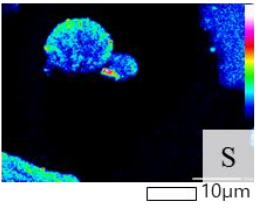

Figure 5. Recovery of gold ions from ammonium thiosulfate solutions with varying additions of Co ion concentrations from 0 to $50 \mathrm{mM}$ (a) without and (b) with $10 \mathrm{mM}$ of $\mathrm{Cu}$ ions in the solution, and (c) SEM photomicrographs with corresponding elemental maps of residue. 
(a)
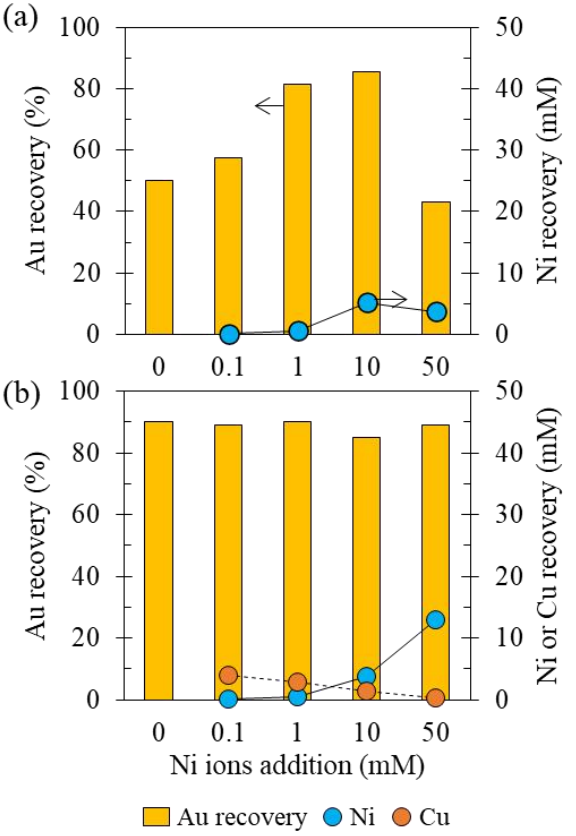

(c)
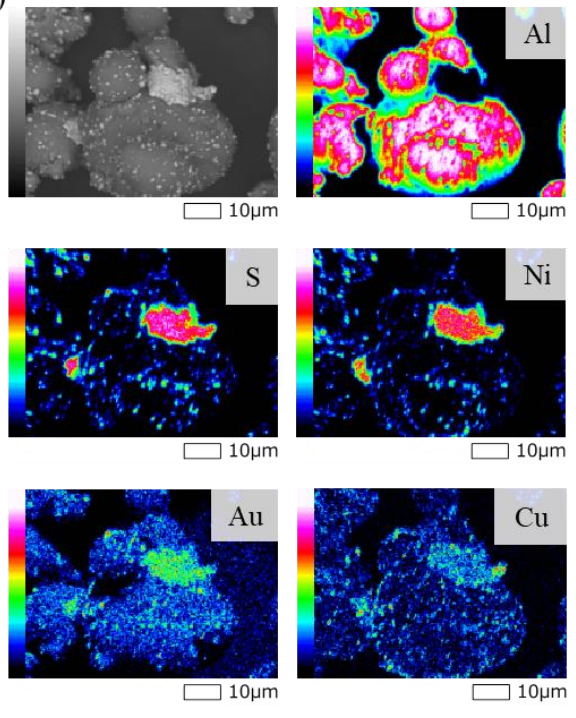

Figure 6. Recovery of gold ions from ammonium thiosulfate solution with varying additions of $\mathrm{Ni}$ ion concentrations from 0 to $50 \mathrm{mM}$ (a) without and (b) with $10 \mathrm{mM}$ of $\mathrm{Cu}$ ions in the solution, and (c) SEM photomicrographs with corresponding elemental maps of the residue.

Figure $7 \mathrm{a}, \mathrm{b}$ shows the recovery of Au ions with varying additions of $\mathrm{Zn}$ ions in the solution from 0.1 to $50 \mathrm{mM}$ without and with $\mathrm{Cu}$ ions in the solution, respectively. Without $\mathrm{Cu}$ ions, $\mathrm{Au}$ recovery increased with the increase in $\mathrm{Zn}$ ion addition, while Au recovery remained at an almost constant value of $90 \%$ with $\mathrm{Cu}$ ions, regardless of the addition of $\mathrm{Zn}$. The SEM photomicrograph with corresponding elemental maps shows that both $\mathrm{Zn}$ and $\mathrm{Cu}$ were recovered on the surface of $\mathrm{ZVAl}$ with $\mathrm{Au}$.

(a)

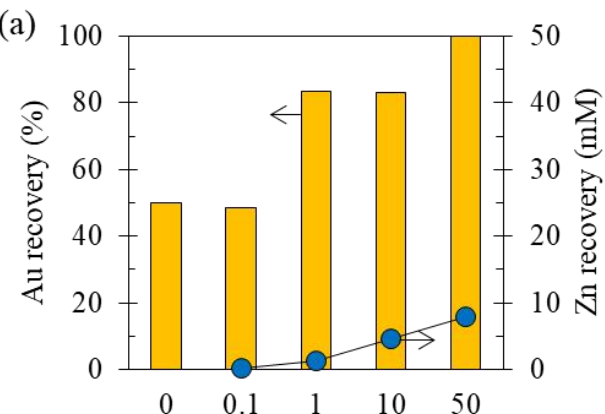

(b)

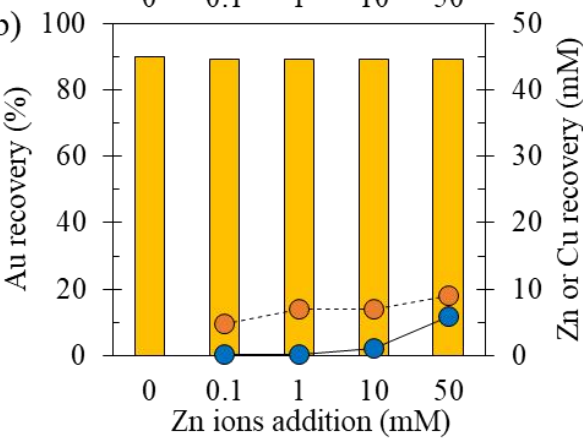

$\square$ Au recovery $\bigcirc \mathrm{Zn} \bigcirc \mathrm{Cu}$ (c)
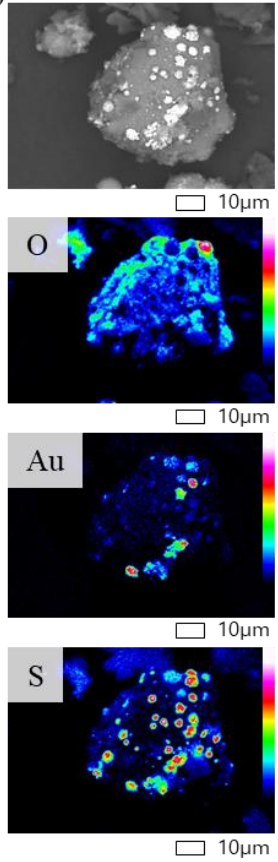
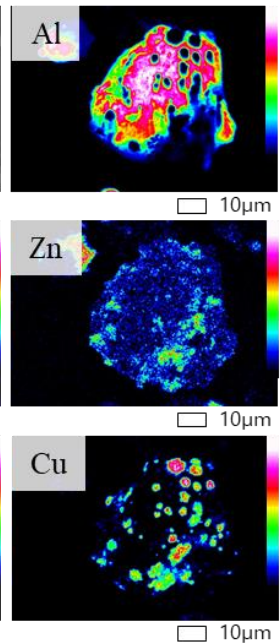

$\square 10 \mu \mathrm{m}$

Figure 7. Recovery of gold ions from an ammonium thiosulfate solution with varying additions of $\mathrm{Zn}$ ion concentrations from 0 to $50 \mathrm{mM}$ (a) without and (b) with $10 \mathrm{mM}$ of $\mathrm{Cu}$ ions in the solution, and (c) SEM photomicrographs with corresponding elemental maps of residue. 
The observed results can be summarized by the following four effects with Figure 8:

- Effect 1: Fe ions precipitated from solution phase, and they did not affect Au recovery.

- Effect 2: $\mathrm{Zn}$ ions and low concentrations of $\mathrm{Co}$ and $\mathrm{Ni}$ ions enhanced Au recovery.

- Effect 3: Higher concentrations of Co and Ni ions suppressed Au recovery.

- Effect 4: In the presence of $\mathrm{Cu}$ ions, the effects of other coexisting metal ions were hindered, i.e., Au recovery was almost constant (the orange section illustrated in Figure 8), regardless of the presence of other coexisting metal ions.

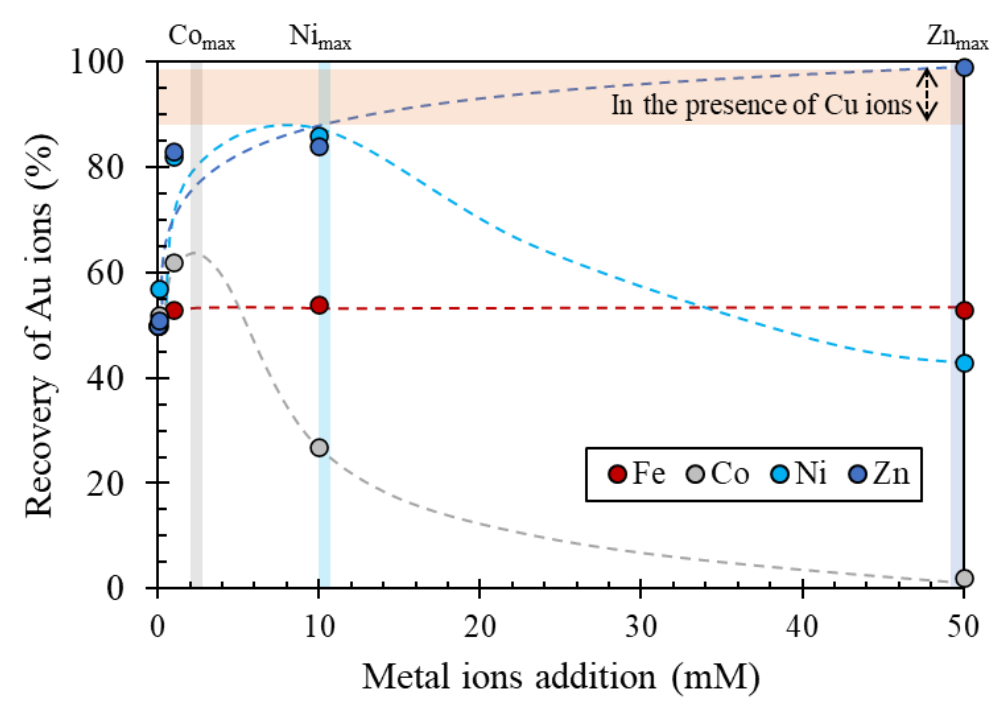

Figure 8. The competitive cementation tendency between $\mathrm{Au}$ ions and other base metal ions reacted on the surface of AC attached to ZVAl in the absence of $\mathrm{Cu}$ ions.

For Effect 1, Fe ions had low solubility and precipitated in the current system and had no effect on Au recovery. Effect 2 (enhanced Au recovery with some of the metal ions) may have occurred due to the formation of new reaction sites for Au deposition: the coexisting metal ions were reduced on the $\mathrm{AC}$ (electron mediator) attached to $\mathrm{ZVAl}$, and the deposit elemental metals acted as secondary electron mediators or new cathode sites for Au deposition. Effect 3 (suppressive effect of the coexisting metal ions on Au recovery) can be interpreted by assuming the competition of cementation reactions (reduction of metal ions) between $\mathrm{Au}$ and coexisting metal ions: a limited amount of electron flow from the donor (ZVAl) was shared with both the Au and coexisting metal ions, causing a decrease in the amount of Au deposition. At a certain concentration of metal ions, the enhanced effect (Effect 2) shifted to suppressive effect (Effect 3 ) and Au recovery reached its maximum at that point. The concentrations of coexisting metal ions promoting maximum Au recovery are shown as $\mathrm{Me}_{\max }$ in Figure 8. The $\mathrm{Me}_{\max }$ concentration was lowest for $\mathrm{Co}$, followed by $\mathrm{Ni}$, then highest for $\mathrm{Zn}$. This order may correspond to the order of the standard redox potential of these metal ions, as shown in Table 1: the standard redox potential for $\mathrm{Co}\left(\mathrm{NH}_{3}\right)_{6}{ }^{3+} / \mathrm{Co}$ is higher than that of the others, suggesting that reductive deposition of Co occurs at lower concentrations. This could be the reason why the enhanced Au cementation occurred at low concentrations of $\mathrm{Co}$. For the $\mathrm{Ni}$ and $\mathrm{Zn}$, the standard redox potentials are lower than $\mathrm{Co}$, and higher concentrations are needed to form the new cathode site for $\mathrm{Au}$ deposition; hence, higher concentrations of $\mathrm{Ni}$ and $\mathrm{Zn}$ were needed for the enhanced $\mathrm{Au}$ recovery. 
Table 1. Standard redox potentials of $\mathrm{Au}, \mathrm{Cu}, \mathrm{Co}, \mathrm{Ni}$, and $\mathrm{Zn}$ in ammonium thiosulfate systems [33-37].

\begin{tabular}{cc}
\hline Metals & $\mathbf{E}^{\mathbf{0}} / \mathbf{V}$ \\
\hline $\mathrm{Au}\left(\mathrm{S}_{2} \mathrm{O}_{3}\right)_{2}{ }^{3-} / \mathrm{Au}$ & 0.27 \\
$\mathrm{Cu}\left(\mathrm{NH}_{3}\right)_{4}{ }^{2+} / \mathrm{Cu}\left(\mathrm{S}_{2} \mathrm{O}_{3}\right)_{2}{ }^{3-}$ & 0.22 \\
$\mathrm{Co}\left(\mathrm{NH}_{3}\right)_{6}{ }^{3+} / \mathrm{Co}\left(\mathrm{NH}_{3}\right)_{x}{ }^{2+}(x$ is mainly 5 under the current conditions $)$ & 0.21 \\
$\mathrm{Co}\left(\mathrm{NH}_{3}\right)_{6}{ }^{3+} / \mathrm{Co}$ & 0.1 \\
$\mathrm{Cu}\left(\mathrm{NH}_{3}\right)_{4}{ }^{2+} / \mathrm{Cu}$ & -0.05 \\
$\mathrm{Cu}\left(\mathrm{NH}_{3}\right)_{4}{ }^{2+} / \mathrm{Cu}_{2} \mathrm{~S}$ & -0.2 \\
$\mathrm{Ni}\left(\mathrm{NH}_{3}\right)_{6}{ }^{2+} / \mathrm{Ni}$ & -0.49 \\
$\mathrm{Zn}\left(\mathrm{NH}_{3}\right)_{4}{ }^{2+} / \mathrm{Zn}$ & -1.04 \\
\hline
\end{tabular}

From an engineering viewpoint, Effect 4 is probably the most noteworthy result here. In the presence of $\mathrm{Cu}$ ions, the effects of other coexisting metal ions were hindered, and high Au recovery was achieved (i.e., $85-95 \%$ ). As show in Table 1, with the exception of Co ions, standard redox potentials of $\mathrm{Cu}$ ions are higher than other metal ions [37,38]. When a high concentrations of $\mathrm{Cu}$ ions coexists, $\mathrm{Cu}$ ions would preferentially be reduced and deposited on AC/ZVAl surfaces [39]. $\mathrm{Cu}$ is an electro-conductor, and its conductivity is much higher than that of other metals (Table 2), and it acts as a high-efficiency secondary electron mediator or cathode site, enhancing electron transfer from ZVAl to Au ions (Figure 9). For that, the effects of other coexisting metal ions (especially the suppressive effect of the ions) on $\mathrm{Au}$ recovery would be minimized in the presence of $\mathrm{Cu}$ ions, and this is schematically illustrated in Figure 9.

Table 2. Conductivity of $\mathrm{Cu}, \mathrm{Zn}, \mathrm{Co}$, and Ni [40,41].

\begin{tabular}{cc}
\hline Metals & Conductivity $\left(\mathrm{S} / \mathbf{m} \times \mathbf{1 0} \mathbf{7}^{\mathbf{a t}} \mathbf{2 5}{ }^{\circ} \mathbf{C}\right)$ \\
\hline $\mathrm{Cu}$ & 5.98 \\
$\mathrm{Zn}$ & 1.7 \\
$\mathrm{Co}$ & 1.6 \\
$\mathrm{Ni}$ & 1.4 \\
\hline
\end{tabular}

(a)

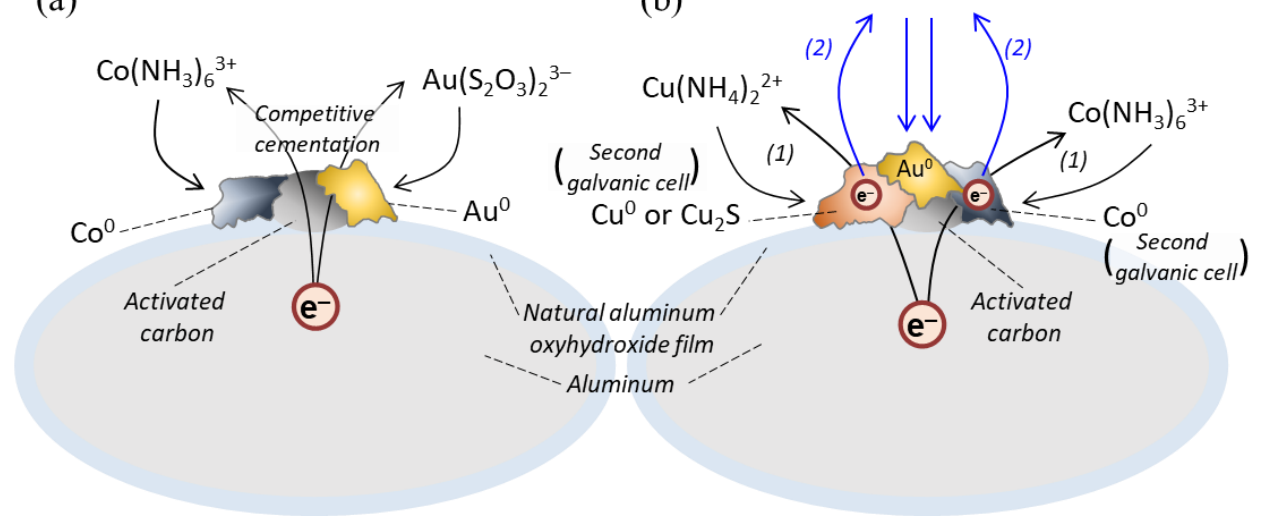

Figure 9. Schematic diagram of the competitive electron transfer from ZVAl to Cu-ammine, Coammine, and Au-thiosulfate complex (a) without and (b) with $\mathrm{Cu}$ ions in the system.

\subsubsection{Recovery of Au Ions from Solutions Containing Various Coexisting Metal Ions}

Figure 10 shows the results of the experiment using the solution containing $10 \mathrm{mM}$ of all base metal ions together with Au ions, like a model solution of pregnant leached solution. The results showed that over $90 \%$ of Au was recovered together with $\mathrm{Co}, \mathrm{Cu}, \mathrm{Zn}$, and $\mathrm{Ni}$, except for Fe ions, and SEM-EDX analysis of the solid product showed that $\mathrm{Au}$ and other base metals were deposited on the same sites. This result confirms that high $\mathrm{Au}$ recovery is achieved even when other base metal ions coexist in the presence of $\mathrm{Cu}$ ions. 
(a)

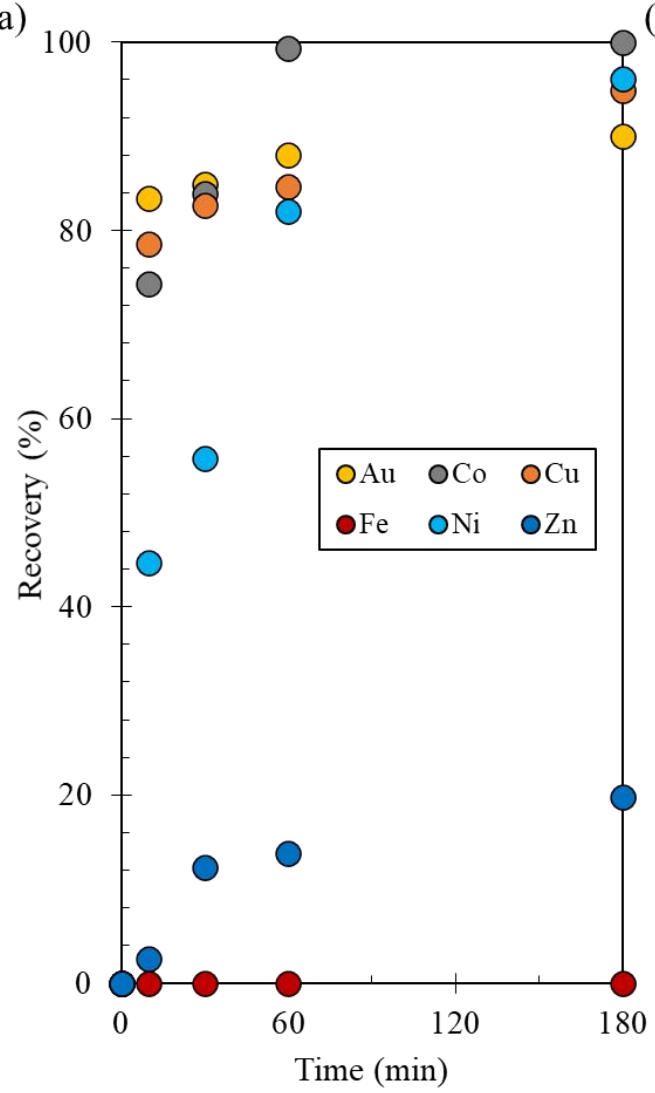

(b)
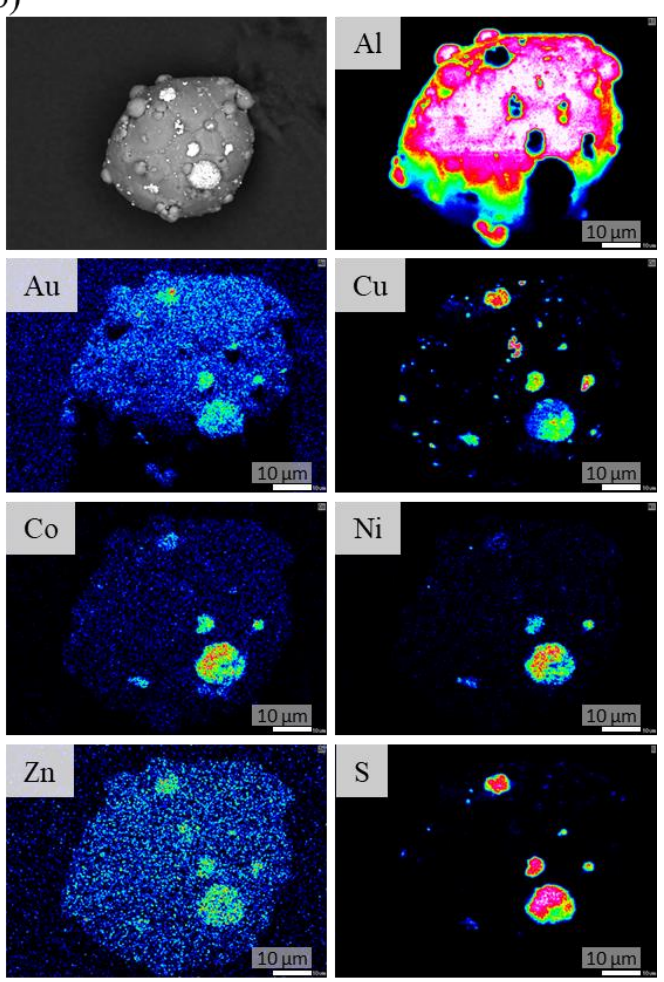

S $\quad .0$

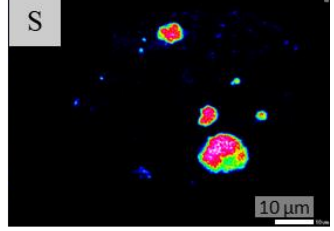

Figure 10. (a) Metal ion recovery from the ammonium thiosulfate solution containing all metal ions (i.e., $\mathrm{Au}, \mathrm{Co}, \mathrm{Cu}, \mathrm{Fe}, \mathrm{Ni}$, and $\mathrm{Zn}$ ions) over time, and (b) SEM photomicrographs and corresponding elemental maps of the residue.

The components/concentrations of the elements are different depending on the type as well as the location of the ores. Based on previous studies, typical $\mathrm{Cu}, \mathrm{Co}, \mathrm{Ni}$, and $\mathrm{Zn}$ concentrations in the ore are: $\mathrm{Cu}$ at about 250 to $5000 \mathrm{ppm}$ [38,42], Co at about 12 to $50 \mathrm{ppm}[39,40], \mathrm{Ni}$ at about $0.002 \%$ to $0.03 \%$ [43,44], and $\mathrm{Zn}$ at about $0.002 \%$ to $1.7 \%$ [5,43-45] (explanation of Fe content was excluded since it does not affect the current leaching/recovery system). In the absence of $\mathrm{Cu}$ ions in the solution, the results showed that $\mathrm{Au}$ recovery decreased from $0.03 \mathrm{Co} / \mathrm{Al}$ mass ratio and $0.04 \mathrm{Ni} / \mathrm{Al}$ mass ratio (in the case of $\mathrm{Zn}$ ion addition, Au recovery continuously increased to over $0.22 \mathrm{Zn} / \mathrm{Al}$ mass ratio) while high and constant $A u$ recovery was obtained in the presence of $\mathrm{Cu}$ ions in the solution regardless of the $\mathrm{Me} / \mathrm{Al}$ mass ratio under the current conditions. In the ammonium thiosulfate system, $\mathrm{Cu}$ ions are essentially employed as a catalyst for enhancing the Au extraction rate by 25 -fold, and successful Au recovery was obtained from a solution containing various base metal ions. Note that a much higher concentration of the elements can be present in the ore and affect the recovery system, even in the presence of proper $\mathrm{Cu}$ ions. In this case, an increase in $\mathrm{ZVAl}$ mass ratio could be expected to increase Au recovery. Thus, this novel recovery technique using galvanic interactions between ZVAl and AC can be employed in the treatment of Au ore containing various elements.

\section{Conclusions}

The present study describes the applicability of a simple and high-efficiency recovery technique by enhanced cementation of galvanic interaction between $\mathrm{ZVAl}$ and $\mathrm{AC}$ for $\mathrm{Au}$ ore processing, which includes:

- Recovery of Au ions from the solution with low Au concentrations of about less than $10 \mathrm{mg} / \mathrm{L}$; 
- Investigation of the effects of various coexisting metal ions that could be present in ore for Au recovery.

The recovery results showed that recovery efficiency slightly decreases as the initial concentration decreases, but still showed over $85 \%$ recovery. Selected coexisting $\mathrm{Cu}, \mathrm{Fe}$, $\mathrm{Co}, \mathrm{Ni}$, and $\mathrm{Zn}$ ions were studied to establish their effects on Au recovery, and the results showed that the Au recovery improved (>85-90\%) when $\mathrm{Cu}$ ions were present in the solution with minimal effects of other competing base metal ions. The recovery of $\mathrm{Au}$ ions from the solution containing $\mathrm{Cu}, \mathrm{Fe}, \mathrm{Co}, \mathrm{Ni}$, and $\mathrm{Zn}$ ions was also carried out and the results showed that even if various metal ions coexisted together with $\mathrm{Au}$ ions in the solution, over $90 \%$ of $\mathrm{Au}$ could be recovered. In the ammonium thiosulfate system, $\mathrm{Cu}$ ions are employed as an essential catalyst; thus, the results showed a high possibility of applicability to Au ore mining processes.

Author Contributions: Conceptualization, S.J., I.P., M.I. and N.H.; methodology, S.J. and N.H.; investigation, S.J. and S.B.; writing-original draft preparation, S.J. and S.B.; writing-review and editing, S.J., I.P., C.B.T., M.I. and N.H.; project administration, S.J., I.P., M.I. and N.H.; funding acquisition, S.J. All authors have read and agreed to the published version of the manuscript.

Funding: This study was financially supported by Japan Oil, Gas and Metals National Corporation (JOGMEC).

Data Availability Statement: Data available on request due to restrictions, as the research is ongoing.

Conflicts of Interest: The authors declare no conflict of interest.

\section{References}

1. Aylmore, M.; Muir, D. Thiosulfate leaching of gold-A review. Miner. Eng. 2001, 14, 135-174. [CrossRef]

2. Tabelin, C.B.; Park, I.; Phengsaart, T.; Jeon, S.; Villacorte-Tabelin, M.; Alonzo, D.; Yoo, K.; Ito, M.; Hiroyoshi, N. Copper and critical metals production from porphyry ores and e-wastes: A review of resource availability, processing/recycling challenges, socio-environmental aspects, and sustainability issues. Resour. Conserv. Recycl. 2021, 170, 105610. [CrossRef]

3. Opiso, E.M.; Aseneiro, J.P.J.; Banda, M.H.T.; Tabelin, C.B. Solid-phase partitioning of mercury in artisanal gold mine tailings from selected key areas in Mindanao, Philippines, and its implications for mercury detoxification. Waste Manag. Res. 2018, 36, 269-276. [CrossRef] [PubMed]

4. Jeon, S.; Tabelin, C.B.; Takahashi, H.; Park, I.; Ito, M.; Hiroyoshi, N. Interference of coexisting copper and aluminum on the ammonium thiosulfate leaching of gold from printed circuit boards of waste mobile phones. Waste Manag. 2018, 81, 148-156. [CrossRef] [PubMed]

5. Aazami, M.; Lapidus, G.; Azadeh, A. The effect of solution parameters on the thiosulfate leaching of Zarshouran refractory gold ore. Int. J. Miner. Process. 2014, 131, 43-50. [CrossRef]

6. Ha, V.H.; Lee, J.-C.; Huynh, T.H.; Jeong, J.; Pandey, B. Optimizing the thiosulfate leaching of gold from printed circuit boards of discarded mobile phone. Hydrometallurgy 2014, 149, 118-126. [CrossRef]

7. Jeon, S.; Tabelin, C.B.; Park, I.; Nagata, Y.; Ito, M.; Hiroyoshi, N. Ammonium thiosulfate extraction of gold from printed circuit boards (PCBs) of end-of-life mobile phones and its recovery from pregnant leach solution by cementation. Hydrometallurgy 2020, 191, 105214. [CrossRef]

8. Molleman, E.; Dreisinger, D. The treatment of copper-gold ores by ammonium thiosulfate leaching. Hydrometallurgy 2002, 66, 1-21. [CrossRef]

9. Ficeriová, J.; Baláz, P.; Villachica, C.L. Thiosulfate leaching of silver, gold and bismuth from a complex sulfide concentrates. Hydrometallurgy 2005, 77, 35-39. [CrossRef]

10. Fleming, C.A.; Mezei, A.; Bourricaudy, E.; Canizares, M.; Ashbury, M. Factors influencing the rate of gold cyanide leaching and adsorption on activated carbon, and their impact on the design of CIL and CIP circuits. Miner. Eng. 2011, 24, 484-494. [CrossRef]

11. Navarro, P.; Vargas, C.; Alonso, M.; Alguacil, F. The adsorption of gold on activated carbon from thiosulfate-ammoniacal solutions. Gold Bull. 2006, 39, 93-97. [CrossRef]

12. Arima, H.; Fujita, T.; Yen, W.-T. Gold Cementation from Ammonium Thiosulfate Solution by Zinc, Copper and Aluminium Powders. Mater. Trans. 2002, 43, 485-493. [CrossRef]

13. Hiskey, J.B.; Lee, J. Kinetics of gold cementation on copper in ammoniacal thiosulfate solutions. Hydrometallurgy 2003, 69, 45-56. [CrossRef]

14. Dong, Z.; Jiang, T.; Xu, B.; Yang, Y.; Li, Q. Recovery of Gold from Pregnant Thiosulfate Solutions by the Resin Adsorption Technique. Metals 2017, 7, 555. [CrossRef] 
15. Jeon, S.; Tabelin, C.B.; Takahashi, H.; Park, I.; Ito, M.; Hiroyoshi, N. Enhanced cementation of gold via galvanic interactions using activated carbon and zero-valent aluminum: A novel approach to recover gold ions from ammonium thiosulfate medium. Hydrometallurgy 2020, 191, 105165. [CrossRef]

16. Vaughan, J.P. The process mineralogy of gold: The classification of ore types. JOM 2004, 56, 46-48. [CrossRef]

17. Cho, K.; Kim, H.; Myung, E.; Purev, O.; Choi, N.; Park, C. Recovery of Gold from the Refractory Gold Concentrate Using Microwave Assisted Leaching. Metal 2020, 10, 571. [CrossRef]

18. Qin, H.; Guo, X.; Tian, Q.; Yu, D.; Zhang, L. Recovery of gold from sulfide refractory gold ore: Oxidation roasting pretreatment and gold extraction. Miner. Eng. 2021, 164, 106822. [CrossRef]

19. Islam, K.; Vilaysouk, X.; Murakami, S. Integrating remote sensing and life cycle assessment to quantify the environmental impacts of copper-silver-gold mining: A case study from Laos. Resour. Conserv. Recycl. 2020, 154, 104630. [CrossRef]

20. Yang, Y.; Gao, W.; Xu, B.; Li, Q.; Jiang, T. Study on oxygen pressure thiosulfate leaching of gold without the catalysis of copper and ammonia. Hydrometallurgy 2019, 187, 71-80. [CrossRef]

21. Gorji, M.; Hosseini, M.R.; Ahmadi, A. Comparison and optimization of the bio-cyanidation potentials of B. megaterium and P. aeruginosa for extracting gold from an oxidized copper-gold ore in the presence of residual glycine. Hydrometallurgy 2020, 191, 105218. [CrossRef]

22. Agorhom, E.A.; Owusu, C. The Effects of Pulp Rheology on Gravity Gold Recovery in Free Milling Gold Ore of the Tarkwaian Systems of Ghana. Miner. Process. Extr. Met. Rev. 2020, 1-6. [CrossRef]

23. Tabelin, C.B.; Silwamba, M.; Paglinawan, F.C.; Mondejar, A.J.S.; Duc, H.G.; Resabal, V.J.; Opiso, E.M.; Igarashi, T.; Tomiyama, S.; Ito, M.; et al. Solid-phase partitioning and release-retention mechanisms of copper, lead, zinc and arsenic in soils impacted by artisanal and small-scale gold mining (ASGM) activities. Chemosphere 2020, 260, 127574. [CrossRef]

24. Park, I.; Hong, S.; Jeon, S.; Ito, M.; Hiroyoshi, N. A Review of Recent Advances in Depression Techniques for Flotation Separation of Cu-Mo Sulfides in Porphyry Copper Deposits. Metal 2020, 10, 1269. [CrossRef]

25. Park, I.; Higuchi, K.; Tabelin, C.B.; Jeon, S.; Ito, M.; Hiroyoshi, N. Suppression of arsenopyrite oxidation by microencapsulation using ferric-catecholate complexes and phosphate. Chemosphere 2021, 269, 129413. [CrossRef] [PubMed]

26. Sahoo, P.; Venkatesh, A. Constraints of mineralogical characterization of gold ore: Implication for genesis, controls and evolution of gold from Kundarkocha gold deposit, eastern India. J. Asian Earth Sci. 2015, 97, 136-149. [CrossRef]

27. Wu, J.; Ahn, J.; Lee, J. Gold deportment and leaching study from a pressure oxidation residue of chalcopyrite concentrate. Hydrometallurgy 2021, 201, 105583. [CrossRef]

28. Adams, M.; Lawrence, R.; Bratty, M. Biogenic sulphide for cyanide recycle and copper recovery in gold-copper ore processing. Miner. Eng. 2008, 21, 509-517. [CrossRef]

29. Wang, Z.; Chen, D.; Chen, L. Application of fluoride to enhance aluminum cementation of gold from acidic thiocyanate solution. Hydrometallurgy 2007, 89, 196-206. [CrossRef]

30. Nguyen, H.; Tran, T.; Wong, P. A kinetic study of the cementation of gold from cyanide solutions onto copper. Hydrometallurgy 1997, 46, 55-69. [CrossRef]

31. Silwamba, M.; Ito, M.; Hiroyoshi, N.; Tabelin, C.B.; Fukushima, T.; Park, I.; Jeon, S.; Igarashi, T.; Sato, T.; Nyambe, I.; et al. Detoxification of lead-bearing zinc plant leach residues from Kabwe, Zambia by coupled extraction-cementation method. J. Environ. Chem. Eng. 2020, 8, 104197. [CrossRef]

32. Arima, H.; Fujita, T.; Yen, W.-T. Using Nickel as a Catalyst in Ammonium Thiosulfate Leaching for Gold Extraction. Mater. Trans. 2004, 45, 516-526. [CrossRef]

33. Liu, X.; Jiang, T.; Xu, B.; Zhang, Y.; Li, Q.; Yang, Y.; He, Y. Thiosulphate leaching of gold in Cu-NH3-S2O32-updated thermodynamic analysis using predominance area and species distribution diagrams. Miner. Eng. 2020, 151, 106336. [CrossRef]

34. Liu, X.; Xu, B.; Yang, Y.; Li, Q.; Jiang, T.; He, Y. Thermodynamic analysis of ammoniacal thiosulfate leaching of gold catalyzed by $\mathrm{Co}(\mathrm{III}) / \mathrm{Co}(\mathrm{II})$ using Eh-pH and speciation diagrams. Hydrometallurgy 2018, 178, 240-249. [CrossRef]

35. Xu, B.; Li, K.; Li, Q.; Yang, Y.; Liu, X.; Jiang, T. Kinetic studies of gold leaching from a gold concentrate calcine by thiosulfate with cobalt-ammonia catalysis and gold recovery by resin adsorption from its pregnant solution. Sep. Purif. Technol. 2019, 213, 368-377. [CrossRef]

36. BC Campus, Appendix: Standard Reduction Potentials by Value. Available online: https://opentextbc.ca/introductorychemistry/ back-matter/appendix-standard-reduction-potentials-by-value-2/ (accessed on 1 April 2021).

37. Senanayake, G.; Senaputra, A.; Nicol, M.J. Effect of thiosulfate, sulfide, copper(II), cobalt(II)/(III) and iron oxides on the ammoniacal carbonate leaching of nickel and ferronickel in the caron process. Hydrometallurgy 2010, 105, 60-68. [CrossRef]

38. Djokic, S.S. Electroless Depositiore on of Metals and Alloys, Modern Aspects of Electrochemistry; Brian, E.C., Conway, E., Ralph, E.W., White, E., Eds.; Springer: Berlin/Heidelberg, Germany, 2002; pp. 51-133.

39. Senanayake, G.; Zhang, X.M. Gold leaching by copper (II) in ammoniacal thiosulfate solutions in the presence of additives. Part II: Effects of residual $\mathrm{Cu}(\mathrm{II}), \mathrm{pH}$ and redox potentials on reactivity of colloidal gold. Hydrometallurgy 2012, 115-116, 21-29. [CrossRef]

40. Compare Metals. Available online: https://metals.comparenature.com/en/copper-vs-cobalt/comparison-6-30-0 (accessed on 15 April 2021).

41. New Medical Device Shielding Requirements and Die Casting (IEC 60601-0-2: 2014—4th Edition). Available online: https: //www.abdiecasting.com/new-medical-device-shielding-requirements-and-die-casting/ (accessed on 26 May 2021). 
42. Örgül, S.; Atalay, Ü. Reaction chemistry of gold leaching in thiourea solution for a Turkish gold ore. Hydrometallurgy 2002, 67, 71-77. [CrossRef]

43. Soltani, F.; Darabi, H.; Badri, R.; Zamankhan, P. Improved recovery of a low-grade refractory gold ore using flotation-preoxidationcyanidation methods. Int. J. Min. Sci. Technol. 2014, 24, 537-542.

44. Melashvili, M.; Fleming, C.; Dymov, I.; Matthews, D.; Dreisinger, D. Dissolution of gold during pyrite oxidation reaction. Miner. Eng. 2016, 87, 2-9. [CrossRef]

45. Murthy, D.S.R.; Kumar, V.; Rao, K.V. Extraction of gold from an Indian low-grade refractor gold ore through physical beneficiation and thiourea leaching. Hydrometallurgy 2003, 68, 125-130. [CrossRef] 